\title{
The Power to Declare Peace Unilaterally
}

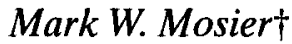

In response to the attacks on the Pentagon and World Trade Center on September 11, 2001, the United States Congress passed a joint resolution authorizing President Bush "to use all necessary and appropriate force against those nations, organizations, or persons he determines planned, authorized, committed, or aided the terrorist attacks." As the "War on Terrorism" moves on with still no end in sight, one wonders: Who has the power to end the War on Terrorism? ${ }^{2}$

This question is important because the existence of a state of war affects both domestic and international law. Domestically, the existence of a state of war has a major impact on civil liberties. The power of the federal government, and its ability to restrict civil liberties, increases during war.' This principle has been recognized by the Supreme Court and is rooted in the text of the Constitution. The Bill of Rights contains two provisions, the Third and Fifth Amendments, that explicitly reduce the protection of individual rights during "time of war." Additionally, the legality of military tribunals, such as those proposed for use during the War on Terrorism, depends on the existence of a state of war.'

$\dagger$ A.B. 1997; J.D. Candidate 2004, The University of Chicago.

1 Authorization for the Use of Military Force, Pub L No 107-40,115 Stat 224, 224 (2001).

2 This Comment does not examine the constitutional validity of a declaration of war against "persons" or "organizations." It considers only the power to end wars properly authorized.

3 Chief Justice Rehnquist recently noted that "[i]t is neither desirable nor is it remotely likely that civil liberty will occupy as favored a position in wartime as it does in peacetime." William H. Rehnquist, All the Laws But One: Civil Liberties in Wartime 224-25 (Knopf 1998).

4 See Korematsu v United States, 323 US 214, 216, 223 (1944) (upholding a "legal restriction[] which curtail[s] the civil rights of a single racial group" during World War II). Some argue that the Court has gone astray in cases like Korematsu when applying the principle of reduced protection of individual rights during war. See, for example, Geoffrey R. Stone, Civil Liberties at Risk Again: A U.S. Tradition, Chi Trib Cl (Feb 16, 2003). Nonetheless, improper application of the principle in cases like Korematsu does not necessarily invalidate the constitutionality of the principle, especially since the principle can be traced to the text of the Constitution. See note 5 and accompanying text.

5 See US Const Amend III ("No Soldier shall, in time of peace be quartered in any house, without the consent of the Owner, nor in time of war, but in a manner to be prescribed by law."); US Const Amend V ("No person shall be held to answer for a capital, or otherwise infamous crime, unless on a presentment or indictment of a Grand Jury, except in cases arising in the land or naval forces, or in the Militia, when in actual service in time of War or public danger.").

6 See In re Yamashita, 327 US 1, 11-12 (1946) (holding that the President's power to try and punish "enemy combatants who have committed violations of the law of war .... is without 
Numerous statutes impact war-time civil liberties. Statutes such as the Alien Enemy $\mathrm{Act}^{\prime}$ give the President increased powers during times of war. Since Congress could simply repeal each individual wartime statute, the expiration of these statutes does not depend solely on the end of the domestic state of war. However, the existence of a state of war importantly affects application of these war-time statutes. Many of these statutes contain provisions that explicitly state that the powers granted to the President expire at the end of the state of war. And because these statutes grant powers that are thought necessary for waging war successfully, Congress is unlikely to repeal them before a war has ended. Thus, ending the domestic state of war is important with respect to war-time legislation despite the fact that Congress could repeal these statutes.

The United States is also affected by the existence of a state of war under international law. The existence of a state of war affects a nation's ability to occupy the territory of an enemy state." The state of war impacts the rights and duties of other nations by implicating the laws of neutrality." Additionally, a declaration of peace that ends the legal state of war arguably triggers the obligation to release enemy combatants, such as those held in Guantanamo Bay, earlier than if no formal steps were taken to end the state of war."

The states of war created under domestic and international law do not necessarily end at the same time or in the same manner. Thus, any discussion of declaring peace must distinguish between ending war for domestic or international purposes. This Comment primarily focuses on declaring peace under domestic law for two reasons. First, it is domestic law, namely the Constitution, to which one must look in order to determine which branch of the United States government is authorized to act. Second, understanding when the domestic state of

qualification ... so long as a state of war exists").

750 USC $\$ 21$ (2000) (allowing war-time seizure of enemy aliens).

8 For a partial listing of statutes expanding executive power during war, see John C. Yoo, War and the Constitutional Text, 69 U Chi L Rev 1639, 1673 n 101 (2002).

9 See Yoram Dinstein, The International Law of Belligerent Occupation and Human Rights, 8 Israel Yearbook Hum Rts 104, 105 (1978) (noting that the occupation of enemy territory terminates when the occupying country withdraws its forces or upon the end of the war).

10 For an account of the continuing importance of the laws of neutrality, see Detlev F. Vagts, The Traditional Legal Concept of Neutrality in a Changing Environment, $14 \mathrm{Am} \mathrm{U} \mathrm{Intl} \mathrm{L}$ Rev 83, 88-89 (1998) ("In the post-World War II epoch the status of neutrality has significantly changed. Some believed that neutrality would disappear.... The idea of neutrality's total disappearance, however, is an exaggeration.").

11 Under the Geneva Conventions, prisoners of war must be released upon the "cessation of active hostilities." Geneva Convention Relative to the Treatment of Prisoners of War, Art 118, 19556 UST 3316,3406, TIAS No 3364 (1949). Without a formal declaration ending the legal state of war, it will be difficult to determine when this occurs in the War on Terrorism. However, a pronouncement that the legal state of war is over would immediately create the obligation to repatriate. 
war terminates goes a long way in determining whether the international state of war has ended, since many of the methods to be considered for ending war domestically will also serve to end war under international law.

Whom, then, does the Constitution authorize to end the War on Terrorism? Answering this question requires knowing where the Constitution places the power to declare peace. Unfortunately, the Constitution makes no mention of the power to declare peace, and the debates of the Constitutional Convention demonstrate that the Framers expected war to end by peace treaty. Because negotiating a peace treaty in the War on Terrorism is unlikely, the original understanding of the power to declare peace cannot determine how the United States can end the war.

To answer that question, historical precedents are useful. For example, following World War II, no peace treaty was negotiated with Germany. Instead, peace was restored by joint presidential and congressional action. ${ }^{13}$ Thus, historical practice lends strong support to the idea that the President and Congress can work together to end the War on Terrorism. However, in the absence of joint action, whether either the President or Congress could act unilaterally to end the legal state of war remains unsettled. ${ }^{14}$

The Framers vested the whole of the war powers in the Congress and President, yet only a few powers were explicitly allocated to either branch. Since the power to declare peace is not one of the enumerated powers, the constitutional text does not explicitly determine whether either of the branches of the government has the authority to act alone to make peace. Does the President's role as Commander-inChief and "sole organ" of foreign affairs give him the power to declare peace? If so, he could act against the will of Congress to restore peace. Does Congress's power to declare war ${ }^{16}$ imply that the power to

12 The question of how the United States can terminate war when it cannot negotiate a peace treaty should not be regarded as unique to the War on Terrorism. Changes in international law made by the United Nations Charter have made peace treaties exceedingly rare. See Yoram Dinstein, War, Aggression and Self-Defence 34 (Cambridge 3d ed 2001) ("In the international armed conflicts of the post-World War II era, States commonly try to avoid not only the term 'war' but also its corollary 'treaty of peace'.").

13 See id at $46 \mathrm{n} 121$.

14 The President would be attempting to act unilaterally if he announced the end of the legal state of war without congressional approval, while Congress would be attempting to act unilaterally if it overrode a presidential veto on a joint resolution announcing the end of the legal state of war.

15 See United States v Curtiss-Wright Export Corp, 299 US 304, 319 (1936) ("The President is the sole organ of the nation in its external relations, and its sole representative with foreign nations.").

16 US Const Art I, $\$ 8, \mathrm{cl} \mathrm{11.} \mathrm{Congress's} \mathrm{failure} \mathrm{to} \mathrm{pass} \mathrm{a} \mathrm{formal} \mathrm{declaration} \mathrm{of} \mathrm{war} \mathrm{in} \mathrm{the}$ War on Terrorism is not important, since it authorized the use of military force, and these two congressional actions are equivalent. See John Hart Ely, War and Responsibility: Constitutional 
declare peace is legislative? If so, Congress could declare peace over the objections of the President by overriding his veto. Does the Framers' expectation that peace would be made by treaty, and the fact that a treaty cannot be made without the President, imply that peace requires the President's concurrence? This would lead to the conclusion that Congress could not declare peace by overriding a presidential veto.

Many scholars argue that Congress can act unilaterally and declare peace by joint resolution." On this reading, the War on Terrorism could come to a legal end, against the wishes of the President, if twothirds of both the House and Senate overrode a presidential veto to pass a joint resolution declaring peace. Some of these scholars assert that the Constitution creates a congressional power to declare peace either by implication from Congress's power to declare war or its power to repeal legislation; ${ }^{18}$ others argue that Supreme Court decisions establish a congressional peace power; ${ }^{19}$ and some claim that Congress established its ability to declare peace by doing so in the past."

This Comment argues that the case for a congressional power to declare peace unilaterally is not sustained on any of these grounds. This Comment further argues that legal precedent and sound public policy support a unilateral presidential power to declare peace. Part I presents the Framers' understanding of the power to declare peace and examines the case law dealing with the peace power. Part II argues against a congressional power to declare peace by joint resolution. Part III argues that a presidential power to declare peace unilaterally is consistent with Supreme Court jurisprudence, and that the circumstances of the War on Terrorism strengthen the functional arguments favoring a unilateral presidential peace power. This Comment concludes that the state of war cannot end against the wishes of the President since his approval is needed for a peace treaty, joint

Lessons of Vietnam and Its Aftermath 3 (Princeton 1993) (explaining that, according to the original understanding of the power to declare war, Congress could exercise its power through legislative authorization); Louis Henkin, Foreign Affairs and the United States Constitution 76 (Oxford 2d ed 1996).

17 For the definitive statement of the power to make peace through congressional resolution, see Henkin, Foreign Affairs and the United States Constitution at 76 (cited in note 16). Professor Henkin acknowledges that the congressional power to make peace was not generally accepted following World War I, but concludes that "the power to end the state of war by resolution is now well established." Id at 371 n 66. For an opposing view, see John C. Yoo, The Continuation of Politics by Other Means: The Original Understanding of War Powers, 84 Cal L Rev 167, 268-69 (1996) (arguing that the Framers "believed that a decision as significant as peace could not be made without [the President's] consent").

18 See Parts II.A.1 and II.A.2.

19 See Part II.A.3.

20) See Part II.A.4. 
congressional-executive agreement, and unilateral presidential proclamation.

\section{The Power to Declare PeACE}

The Framers envisioned that the President would play a vital role in the peace process, and thus rejected several measures that would have given Congress unilateral power to declare peace. The Supreme Court initially adopted the Framers' view that peace could be achieved only through treaty. While the Court has moved away from this position, it has not departed from the Framers' belief that the President must be involved in the peace process.

This Part examines the power to declare peace. Part I.A reviews the debates of the Constitutional Convention and concludes that the Framers expected the President to be involved in making peace. Part I.B examines the Supreme Court decisions addressing the power to terminate the legal state of war and concludes that the President's approval is needed to declare peace.

\section{A. Original Understanding of the Peace Power}

The text of the Constitution makes no mention of the power to declare peace. ${ }^{21}$ However, the debates at the Constitutional Convention reveal that the Framers rejected a congressional power to declare peace and expected peace to occur through the negotiation of a peace treaty.

Several important inferences can be drawn from the Framers' expectation that peace would be made by treaty. We can infer that the Framers intended to foreclose unilateral presidential action, because a treaty requires the concurrence of the President and two-thirds of the Senate. On the other hand, while the President's veto power over legislation is subject to congressional override, his treaty power is absolute: No treaty can be made without the President's agreement. Furthermore, the ability to make peace by congressional resolution is questionable as a matter of original intent because it creates a role for the House that does not exist in the treaty process.

21 The absence of a peace power is surprising considering that this power was included in the Articles of Confederation, which granted the Continental Congress the "sole and exclusive right and power of determining on peace and war." Articles of Confederation Art IX (1777). Because the Continental Congress was the only branch of the national government, vesting the peace power in the Continental Congress was necessary, not to show that the power was legislative. but to exclude the power from the states.

22 See Joseph Story, 2 Commentaries on the Constitution of the United States $\$ 1173$ at 98 (Little, Brown 3d ed 1858) (explaining that a congressional power to make peace was unanimously rejected at the Convention in favor of making peace through treaty). 
At the Constitutional Convention, an amendment was proposed to grant Congress the power to declare peace. ${ }^{23}$ Pierce Butler offered it in order "to give the Legislature the power of peace, as they were to have that of war." ${ }^{24}$ The belief that the power to begin and end war should reside in the same body was common at the time of the Convention, ${ }^{25}$ and was supported by Blackstone. ${ }^{2 \hbar}$ Despite the contemporaneous view that these powers should reside in the same hands, this proposal was unanimously rejected. ${ }^{27}$ Though the records of the debate are brief, the reasons given are significant. According to Oliver Ellsworth, "[t]here is a material difference between the cases of making war and making peace. It should be easier to get out of war, than in to it. War also is a simple and overt declaration, peace attended with intricate and secret negotiations.." George Mason added that "[h]e was for clogging, rather than facilitating war; but for facilitating peace. ${ }^{29}$

When the Framers decided to include the President in the treatymaking process, they reiterated the importance of negotiating treaties in secrecy. A proposal requiring two-thirds consent of both the Senate and House of Representatives was rejected out of concern for secrecy. As Roger Sherman of Connecticut argued, "the necessity of secrecy in the case of treaties forbade a reference of them to the whole Legislature.","

Madison's concern about the effect that the changes to the treaty power would have on the peace process led him to propose two peace treaty exceptions to the general treaty power. His first proposal would have required only a majority vote from the Senate to consent to a peace treaty. ${ }^{31}$ The second proposal would have "authorize[d] a con-

23 See James Madison, Journal of the Federal Convention 549 (Scott, Foresman 1898) (E.H. Scott, ed).

24 Id.

25 See, for example, id at 548 (noting that, in the debate over the power to declare war, Charles Pinckney thought that "[i]t would be singular for one authority to make war, and another peace").

26 See William Blackstone, 1 Commentaries on the Laws of England *250 ("[W]herever the right resides of beginning a national war, there also must reside the right of ending it, or the power of making peace.").

27 See Madison, Journal of the Federal Convention at 549 (cited in note 23).

28 Id at 548 . While it would be easy to read the need for "intricate and secret negotiation" as a basis for preferring the President over Congress in determining peace, it is important to note that at the time that this statement was made. the treaty power lay solely with the Senate. The relative ease with which peace would result was based on the fact that treaties required only a majority vote in the Senate, while war required a majority in both the House and Senate. The restructuring of the treaty power to authorize the President to make treaties with the advice and consent of two-thirds of the Senate clearly promoted the aim of facilitating negotiations, but it apparently did so at the expense of the other justification for leaving the power to declare peace as part of the treaty power - that making peace should be easier than making war.

\footnotetext{
29 Id.

30 Id at 680.

31 See id at 682 .
} 
currence of two-thirds of the Senate to make treaties of peace, without the concurrence of the President." ${ }^{, 32}$ The combined effect of these two proposals would have been to make it easier to declare peace than war."

If the Framers' primary goal had been simply to facilitate peace, they would have adopted Madison's amendments. However, the proposals were rejected on grounds that support the President's primacy in the peace process. ${ }^{34}$ Not only did the President have an advantage in his ability to negotiate in secrecy, but, unlike the Senate which represented the interests of the states, he alone represented the whole nation. This argument was presented by Gouverneur Morris, who argued "that no peace ought to be made without the concurrence of the President, who was the general guardian of the national interests."," The Framers rejected Madison's proposals because they believed that the President should play an important role in the treaty process, despite the fact that the proposals would have made it easier to declare peace than to declare war.

Madison did not trust the President to protect the national interests. He thought that the President "would necessarily derive so much power and importance from a state of war, that he might be tempted, if authorized, to impede a treaty of peace.".36 Other Framers shared this concern, but their fears were assuaged by the fact that Congress had other checks on the President's ability to wage war. Nathaniel Gorham argued that Madison's proposal to allow the Senate to declare peace without the President was not necessary since "the means of carrying on the war would not be in the hands of the President, but of the Legislature." "?

From the text of the Constitution, it is evident that the Framers envisioned that Congress would check the President's war-making power through its "power of the purse." The Constitution gives Congress the power "[t]o raise and support Armies, but no Appropriation

32 Id.

33 Under Madison's proposals, the power to declare peace would track the power to declare war, but peace would be easier in all cases as a result of the exclusion of the House of Representatives. A declaration of war, like any other act of Congress, would require a majority of both the House and Senate and the consent of the President; or, if the President's concurrence was lacking, then the declaration would require two-thirds of both the House and Senate to override the veto. The Madison proposals would require the concurrence of the President and a simple majority of the Senate, while allowing the Senate to override the President's objections by a two-thirds vote.

34 See id at 683,686 (reporting that the first proposal was initially accepted, but then dropped the next day, while the second proposal was rejected on its only vote).

35 See id at 682 .

36 Id.

37 Id. 
of Money to that Use shall be for a longer Term than two years." limiting appropriations to two years, the length of a term in the House, the Framers increased the popular check placed on the war-making power. Representatives cannot vote to fund the war longer than their next term, thus assuring that the issue of whether to continue funding the war will be an issue in their reelection campaigns. Congress's ability to check the President through its appropriations power was important to the Framers: It reduced the likelihood that the President would abuse the fact that peace could not be made without his consent.

\section{B. Case Law Addressing the Power to Declare Peace}

The Supreme Court's most recent statement on the power to terminate war was made in Hamilton $v$ Kentucky Distilleries \& Warehouse $\mathrm{Co:}^{3 .}$ The "technical state of war [is] terminable only with the ratification of a treaty of peace or a proclamation of peace." Cases prior to Hamilton show that the Court originally adopted the Framers' view that peace could occur only by treaty. Problems arising after World War I led the Supreme Court in Hamilton to add proclamations of peace as an additional method by which wars could be terminated. More recent cases do not affect the view set forth in Hamilton.

\section{Cases prior to Hamilton.}

In 1796, the Supreme Court adopted the Framers' view that peace should occur through the treaty process. In Ware $v$ Hylton, Justice Chase announced that "[a] war between two nations can only be concluded by treaty." "This holding was tested at the conclusion of the Civil War; a war to suppress an insurrection could not be properly concluded by treaty because the enemy, once defeated, remained part of the country.

The post-Civil War Supreme Court recognized this problem and announced a different method for ending domestic war. In United States $v$ Anderson, ${ }^{43}$ the Court accepted the existing law that a peace treaty was required in a foreign war, but held that "in a domestic war, like the late one, some public proclamation or legislation would seem to be required to inform those whose private rights were affected by

\footnotetext{
US Const Art I, $\$ 8, \mathrm{cl} 12$.

251 US 146 (1919).

Id at 161 .

3 US (3 Dall) 199 (1796).

Id at 236.

76 US ( 9 Wall) 56 (1869).
} 
it, of the time when it terminated." determine the end of the Civil War, "it is only necessary to notice the proclamation of the President, of August 20th, 1866, and the act of Congress of the $2 \mathrm{~d}$ of March, 1867., ${ }^{45}$

Two years later, the Court again applied its rule for ending domestic war in The Protector. ${ }^{4 h}$ The Court stated that it was necessary "to refer to some public act of the political departments of the government to fix the dates; and, for obvious reasons, those of the executive department, which may be, and, in fact, was, at the commencement of hostilities, obliged to act during the recess of Congress, must be taken." ${ }^{, 47}$ The Court then pointed to two presidential proclamations "declaring that the war had closed."

The Civil War ended through presidential proclamation; however, the Court explicitly stated that this method was only available in domestic wars." Following the Spanish-American War, the Court, in $J$. Ribas y Hijo v United States," revisited the issue and reaffirmed its prior holding, refusing to extend the option of peace by proclamation to foreign wars. President McKinley issued a proclamation ending hostilities in August 1898, and a treaty of peace was concluded in April 1899.' Ribas, a Spanish corporation whose ship was seized by the United States military and held until the conclusion of the peace treaty, sought to "recover on a quantum meruit the value of the use of the vessel between [the presidential proclamation and peace treaty].", The Court did not allow recovery since "[a] state of war did not in law cease until the ratification in April, 1899, of the treaty of peace.",33 Thus, by denying recovery, the Court refused to recognize that a presidential proclamation, in the absence of a peace treaty, could end a foreign war. Instead, the Court reinforced the distinction between domestic and foreign wars that it had drawn in Anderson and The Protector.

\section{Hamilton v Kentucky Distilleries \& Warehouse Co.}

The events surrounding the end of World War I made it difficult for the courts to determine when the state of war had terminated. Following the conclusion of hostilities, the United States signed the

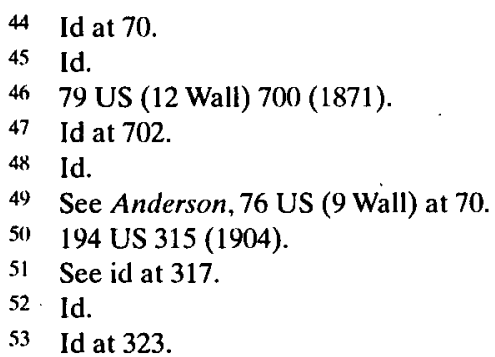


Treaty of Versailles and President Wilson, attempting to end the legal state of war with Germany, submitted the treaty to the Senate for its advice and consent. ${ }^{5 .}$ Wilson, although concerned that the treaty might not receive the Senate's consent, denied having the power to end the war by presidential proclamation." The Senate finally voted on, but rejected, the treaty, returning it to the President without consent, which meant that it could not be ratified." Congress attempted to end the war by passing a joint resolution, but the House failed to override President Wilson's veto." Congress later passed a peace resolution that was signed by President Harding. ${ }^{59}$ Peace treaties were then negotiated with each enemy, ${ }^{\text {sil }}$ and upon ratification of those treaties, Harding issued a presidential proclamation declaring peace. ${ }^{\text {.1 }}$

In Hamilton, the Supreme Court was forced to interpret the WarTime Prohibition Act, ${ }^{62}$ which made it unlawful to sell "distilled spirits" prior to "the conclusion of the present war and thereafter until the termination of demobilization." ${ }^{137}$ The respondent, the owner of a liquor warehouse, brought an action seeking to enjoin the enforcement of the Act. While considering the validity of the Act, the Court twice addressed the issue of when the legal state of war ended. The Court first noted that the "technical state of war [was] terminable only with the ratification of a treaty of peace or a proclamation of peace.", Later in the opinion, the Court stated that "the period of war has been held to extend to the ratification of the treaty of peace or the proclamation of peace." peace and a proclamation of peace as the only methods for ending a state of war.

54 See Manley O. Hudson, The Duration of the War between the United States and Germany, 39 Harv L Rev 1020, 1031 (1926).

55 See Statement of President Wilson, 66th Cong, 1st Sess, in 58 Cong Rec S 4177 (Aug 22, 1919) ("I feel constrained to say ... not only that in my judgment I have not the power by proclamation to declare that peace exists, but that I could in no circumstances consent to take such a course prior to the ratification of a formal treaty of peace.").

56 See Hamilton, 251 US at 160.

57 See Hudson, 39 Harv L Rev at 1031 n 40 (cited in note 54).

58 See id at 1033.

59 See Declaration Terminating War with Germany and Austria-Hungary, Pub Res No 67-8, 42 Stat 105 (1921).

6) See Treaty of Peace between the United States and Germany, 42 Stat 1939, Treaty Ser No 658 (1921); Treaty of Peace between the United States and Austria. 42 Stat 1946, Treaty Ser No 659 (1921); Treaty of Peace between the United States and Hungary, 42 Stat 1951, Treaty Ser No 660 (1921).

6) See Presidential Proclamation Declaring Peace with Germany, 42 Stat 1944 (1921).

62 Pub L No 65-243, 40 Stat 1045 (1918).

63 Id at 1046.

64 Hamilton, 251 US at 161.

65 Id at 165. 
The Court cited J. Ribas y Hijo, The Protector, and Anderson to support its claim that the state of war could end only by peace treaty or proclamation of peace. ${ }^{\text {th }}$ These cases provide support for the Court's claim insofar as J. Ribas y Hijo recognized a peace treaty as ending the state of war, and The Protector and Anderson recognized presidential proclamations of peace as ending the state of war. In adopting this rule, the Court glossed over the post-Civil War distinction between ending domestic and foreign wars. A presidential proclamation of peace that had been recognized as ending the Civil War was now cited to support the proposition that a proclamation of peace could end a foreign war.

The timing of the Hamilton decision could have played a role in the Court's addition of "proclamation of peace" as a method of ending foreign wars. When the Court was deciding Hamilton, the possibility that a peace treaty would not be concluded was no longer purely hypothetical. The Senate had voted against ratification of the Treaty of Versailles on November 19, 1919." The Court heard arguments in Hamilton the next day, November 20, and issued its opinion less than a. month later on December 15,1919. As a result of the Senate's failure to consent to the Treaty of Versailles, the Court may have realized that if it allowed only a peace treaty to end the legal state of war, the war might never end.

The Court did not explicitly state that a proclamation of peace must come from the President. However, it is unlikely that the Court thought that a congressional resolution could serve as a proclamation of peace. Each of the Civil War cases to which the Court cited for the proposition that war can end by proclamation of peace explicitly refers to proclamations of peace made by the President. ${ }^{69}$ Additionally, Anderson distinguishes between a "public proclamation and legislation." ${ }^{\text {,0 }}$ Finally, a number of war-time statutes discussed by the Court clearly stated that the proclamation of peace was to be made by the President." These factors make it unlikely that the Court would intend the phrase "proclamation of peace" to be interpreted so broadly as to include congressional resolutions without explicitly saying as much. Thus, when the Court recognized that a proclamation of peace could end war, it was recognizing a presidential power to proclaim peace.

66 Id.

67 Id at 160.

68 Id at 146.

69 See text accompanying notes $43-48$.

70) Anderson, 76 US at 70.

71 See Hamilton, 251 US at $165 \mathrm{n} 1$ (listing statutes that expire at the end of the war, a number of which explicitly mention a "proclamation by the President"). 
The Court not only failed to include congressional resolution as a method of declaring peace in a foreign war, but it excluded this method by making treaty and proclamation the only methods. The circumstances under which the Court decided this case are once again important. Permitting a congressional resolution to end the war, when a treaty has been negotiated and needs only Senate approval, would effectively allow the Senate to choose the House over the President as its partner in the peace process. If there was strong opposition in the Senate to a peace treaty negotiated by the President, as was the case with the Treaty of Versailles, the Senate might prefer passing a resolution instead of acting upon the treaty. The Court may have worried that permitting congressional resolutions to be used to declare peace would facilitate an end-run around the traditional peace process.

Allowing the President to declare peace by proclamation could, as a general matter, result in the President attempting an end-run around the traditional peace process by issuing a proclamation instead of negotiating a treaty. However, the Court was not faced with this difficulty in Hamilton. It did not have to worry about this possibility because the President had already performed his traditional role by negotiating the treaty and submitting it to the Senate for its advice and consent.

\section{Cases following Hamilton.}

On November 14, 1921, upon ratification of the peace treaty, President Harding issued a presidential proclamation stating that the legal state of war with Germany had concluded four months earlier on July 2 of that year. ${ }^{2}$ Under the rule set forth in Hamilton, this action should have been considered sufficient to end the war. In Miller $v$ Rouse," Judge Learned Hand heard an Alien Property Custodian claim for a demand served on July 5, 1921. Judge Hand denied the claim because it was made "three days after the declaration of peace as now promulgated by the President's recent proclamation." Thus, consistent with Hamilton, Judge Hand took the presidential proclamation of peace as setting the date of the end of the legal state of war.

Two years after Harding's presidential proclamation, in Commercial Trust Co v Miller," the Supreme Court was faced with determining whether the Trading with the Enemy Act ${ }^{7 /}$ was still valid. This case has been relied upon for establishing a congressional power to declare

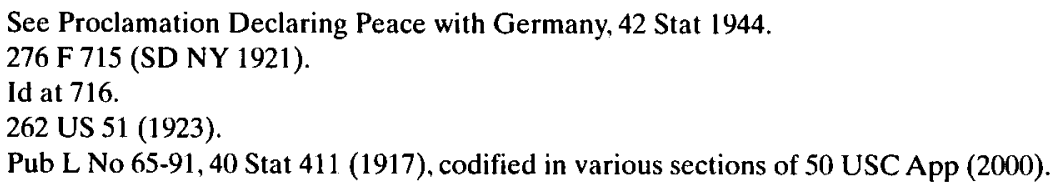


peace. In it, the Court stated that "the power which declared the necessity is the power to declare its cessation, and what the cessation requires. The power is legislative." Read out of context, this statement appears to grant Congress the power to declare peace. When placed into context, however, it is clear that the Court was simply referring to the power to determine whether the Trading with the Enemy Act should remain in effect.

The Court's statement responded to an argument claiming that the statute was no longer valid because the war was over. ${ }^{7 *}$ Congress has the power to determine the necessity of war-time legislation; the Court determined that it was unfit to determine when this necessity no longer existed, so it looked to Congress for this determination." Congress had passed a resolution terminating many of its war-time statutes, but had excluded the Trading with the Enemy Act. Based on this congressional action, the Court determined that the legislative intent was to keep the Act in force. In concluding that the statute was valid, the Court did not need to address the power to end the state of war.

Following World War II, the Court was once again faced with determining when war-time statutes expired. In Ludecke $v$ Watkins, ${ }^{\mathrm{N}}$ the Court addressed the question whether the Alien Enemy Act of $1798^{\text {*1 }}$ had expired. This statute authorized the President to remove aliens from the United States during "declared war." The Court was not faced with the constitutional question of whether the state of war had ended, but with a question of statutory interpretation: whether the "declared war," as defined by the statute, had ended.

The Court examined the legislative history of the Act and determined that there was no reason to believe that Congress intended the Act to expire prior to the end of the legal state of war. The Court also noted that it was clear that the state of war had not ended. ${ }^{* 4}$ Since the state of war had not ended, and the Court had interpreted the statute to remain in effect until the termination of the state of war, the Court

\footnotetext{
Commercial Trust, 262 US at 57.

Id.

79 The Court said:
}

A court cannot estimate the effects of a great war and pronounce their termination at a particular moment of time, and that its consequences are so far swallowed up that legislation addressed to its emergency had ceased to have purpose or operation with the cessation of the conflicts in the field.

Id.

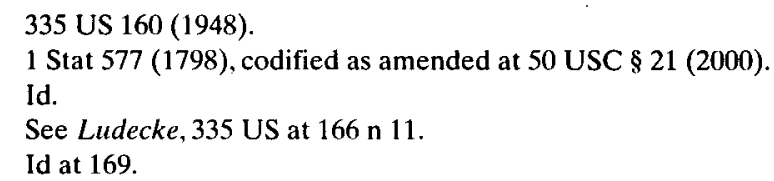


concluded that the statute was still in effect. As a result, the Court had no need to consider how the state of war could end.

Although the Court was simply interpreting the Alien Enemy Act, some commentators have relied on language from this opinion to argue that Ludecke, not Hamilton, states the Court's view on the power to declare peace. ${ }^{\text {.5 }}$ In Ludecke, the Court, during a discussion of whether the President's statutory power had expired, noted that " " $[t]$ he state of war' may be terminated by treaty or legislation or Presidential proclamation. Whatever the mode, its termination is a political act.",

This statement should be read as referring to the means of terminating the "state of war" with respect to the Act, not of terminating the legal state of war. This reading is proper in light of the fact that the Court made this statement while interpreting the statute and because the rest of the Court's discussion on the power to end the legal state of war not only makes no attempt to depart from, but is consistent with, Hamilton.

The Court's discussion of whether the war with Germany had ended is important to note. Justice Frankfurter, quoting a presidential proclamation, wrote: "The political branch of the Government has not brought the war with Germany to an end. On the contrary, it has proclaimed that 'a state of war still exists." ${ }^{\text {k7 }}$ No treaty had been concluded, so Frankfurter looked to the presidential proclamation to determine whether peace had been restored. This analysis is exactly in line with Hamilton and in no way suggests that the Court was attempting to change the power to restore peace.

The Court's footnote to the statement "'the state of war' may be terminated by treaty or legislation or Presidential proclamation" also suggests that the Court was listing the methods by which the statute, not the war, could be terminated. Congress, according to the Court, could "provide either by a day certain or a defined event for the expiration of a statute. But when the life of a statute is defined by the existence of a war, Congress leaves the determination of when a war is concluded to the usual political agencies of the Government." gress can determine when a statute expires; the usual political agen-

¿5 See Part II.A.3.

$86 \quad 335 \mathrm{US}$ at $168-69$.

87 Id at 170, quoting Presidential Proclamation 2714,3 CFR \$\$ 99-100 (1957).

8* Ludecke, 335 US at 168. The Court's placement of the term "state of war" within quotaion marks is interesting. The reference to "the state of war" in the same paragraph (just three sentences later), id at 169 , without quotation marks makes their initial use even more intriguing. One possible explanation is that the quotation marks are used to distinguish between the state of war for purposes of the statute and the state of war in its technical sense. When the phrase is used without quotes it seems that the Court is referring to war in the technical sense.

89 Id at $169 \mathrm{n} 13$. 
cies, the President or the President and Senate, can end war through presidential proclamation or peace treaty, respectively. Thus, "the state of war" within the meaning of the statute can be ended by peace treaty, legislation, or presidential proclamation.

The reference to the usual political agencies in this footnote shows that the Court limited the making of peace to those methods already recognized, and did not attempt to set a new standard. After Hamilton, it was clear who the "usual political agencies" were: the President or the President and Senate.

The Ludecke Court did not create a new method for terminating foreign wars. The Court did nothing more than determine whether the Act had expired. Thus, the standard announced by the Court in Hamilton-that the "technical state of war [is] terminable only with the ratification of a treaty of peace or a proclamation of peace" remains the Court's current statement of the methods of terminating the state of war.

\section{Declaring Peace by Congressional Resolution}

The case law suggests that war can end only by treaty or presidential proclamation. This view follows the Framers' original understanding that the President would be involved in negotiating peace. Nevertheless, many commentators have argued that Congress possesses the power to declare peace. Part II.A analyzes, and ultimately rejects, arguments that Congress possesses the power to declare peace through a joint resolution. The next question is whether Congress should be able to override a presidential veto and end the legal state of war. Part II.B examines a number of arguments that favor recognizing a congressional power to declare peace and finds none of them convincing.

\section{A. Arguments Claiming Congress Has the Power to Declare Peace}

In Hamilton, the Supreme Court asserted that war can only be terminated by peace treaty or proclamation of peace, seemingly precluding the termination of the legal state of war by congressional resolution. Commentators have nonetheless advanced a number of different arguments claiming that Congress has the power to declare peace. Four of these arguments are examined below: the power to declare peace is implicit in Congress's power to declare war; Congress can end war by repealing its declaration; Supreme Court decisions have created a congressional peace power; and Congress has ended wars by resolution in the past, thus establishing its power to do so. None of 
these arguments succeeds in demonstrating that Congress has the power to declare peace.

1. Constitutional authority implicit in power to declare war.

Professor Louis Henkin in his book, Foreign Affairs and the United States Constitution, argues that " $[\mathrm{t}]$ he power 'of determining on peace and war' surely implies also a corollary power to decide that war should end." The difficulty with this argument is that Congress does not possess the power "of determining on peace and war." This power does not come from the Constitution; instead, this was the power possessed by the Continental Congress under the Articles of Confederation." The Constitution merely grants Congress the power to "declare War," and it is unclear that the "corollary power to decide that war should end" derives from this power.

The argument can be based on Congress's constitutional power to declare war and its receipt of powers "necessary and proper" to carrying out this enumerated power. Thus, one could argue that the power to end war is a necessary and proper extension of the power to declare it. This is the strongest form of the pro-Congress argument, since it attempts to find congressional authority within the Constitution itself.

This argument is strengthened by the fact that, at the time of the Founding, it was generally thought that the power to declare war implied the power to declare peace. Yet the proposed amendment at the Constitutional Convention to grant Congress the power to "declare war and peace" makes it clear that the Framers did not think that one power implied the other." Not only did the Framers not think that this power was implied, but their rejection of the proposed amendment displayed a desire to place the two powers in separate bodies. The Framers' choice of giving Congress the power to declare war and the treaty-makers the power to declare peace refutes the argument that one power necessarily implies the other."

The power to declare war does grant Congress considerable power over war. In Bas $v$ Tingy," the Supreme Court recognized that Congress had the power to limit the scope of war. In Bas, Justice Chase wrote: "Congress is empowered to declare a general war, or

9) Henkin, Foreign Affairs and the United States Constitution at 76 (cited in note 16).

92 See Articles of Confederation Art IX (1777).

9.3 See text accompanying notes 23-27.

94 For a district court opinion supporting this argument, see United States v Hicks, $256 \mathrm{~F}$ 707.710 (WD Ky 1919) (reasoning that "the Constitution, while in express terms giving Congress' the sole power of declaring war, in no way so expresses itself as to give that body any authority itself to terminate it").

954 US (4 Dall) $37(1800)$. 
congress may wage a limited war; limited in place, in objects, and in time." "The "declare War" power, according to Chase, allows for more than just a "yes or no" determination of whether to commence war; it allows for Congress to choose the type of war. ${ }^{47}$ One might argue that if Congress has the power to determine the scope of the war, it must have the power to determine when the war has come to an end.

However, Bas should not be read to grant Congress the power to terminate war. Justice Chase only recognized the power of Congress to create limitations while authorizing the war; he did not recognize a power to restrict the President's authority after hostilities have begun. There is a considerable difference between the power to place restrictions ex ante on the President's ability to wage war and the power to determine, once the war has started, that it should end. The President's ability to wage war successfully is not as severely compromised by ex ante restrictions since he can incorporate those decisions into his war plans. This power is markedly different than the power being claimed here - the power to place restrictions directly on the President's ability to wage war during hostilities.

\section{Power to repeal legislation.}

According to Professor Edward Corwin, Congress derives the power to restore peace from its power to repeal legislation." On this view, Congress has the power to repeal any piece of legislation that it passes, so it can repeal its declaration of war (or authorization of the use of force) and effectively end the war. Any such repeal would be functionally equivalent to a peace resolution since each would require a two-thirds majority to override a presidential veto. Since Congress can achieve the same result through an equivalent piece of legislation, whether the legislation is called a "declaration of peace" or a "repeal of war" should not matter.

Congress can repeal any legislation that it passes. However, this does not imply that it can terminate all that the legislation initiated. Professor Quincy Wright pointed out that Corwin's argument "fails to recognize the distinction between an act of legislation and a resolution creating a status or condition. Congress cannot, in general, repeal resolutions of the latter class, of which resolutions admitting states to

96 Id at 43. Many scholars recognize this congressional power as well. See Michael D. Ramsey, Textualism and War Powers, 69 U Chi L Rev 1543, 1620 (2002) ("Congress can exercise some strategic direction of a war through its declare-war power.").

97 See Ramsey, 69 U Chi L Rev at 1620 (cited in note 96) ("Congress's decision to declare war was not a binary choice, involving total war or nothing; rather, Congress was entitled to set limited goals for the hostilities.").

98 See Edward S. Corwin, The Power of Congress to Declare Peace, 18 Mich L Rev 669 , 674-75 (1920). 
the Union, incorporating territory, admitting nationals to citizenship, etc., are examples." "Professor John Mathews rejected Corwin's argument for similar reasons: "Congress can pass an act or joint resolution admitting a state into the Union, but it would hardly be maintained that, after a state has once been admitted, Congress could expel it by a simple repeal of the act admitting it.", Similarly, the repeal of a declaration of war does not necessarily terminate the state of war created by that declaration.

\section{Supreme Court precedent.}

Some scholars have claimed to find a congressional power to declare peace in Supreme Court precedent. Professor Henkin supports his argument that Congress can declare peace unilaterally by citing two Supreme Court opinions. In support of his claim that Congress's power to restore peace is "now well established," Henkin quotes Commercial Trust: "[T]he power which declared the necessity, is the power to declare its cessation and what the cessation requires. The power is legislative." Reading this quote as referring to war implies that the Court is recognizing that the power to end war is legislative, not executive. However, the Court was referring, not to war, but to an act of Congress. ${ }^{102}$ Under this reading, the Court merely stated that the power to determine when an act of Congress expires is legislative, not judicial.

Henkin also cites Ludecke for the proposition that " " $[\mathrm{t}] \mathrm{he}$ State of War' may be terminated by treaty or legislation or Presidential proclamation." "The "state of war" that the Court refers to in Ludecke was the period of time in which the statute remained in effect. ${ }^{104}$ The quotes taken from Commercial Trust and Ludecke, when read out of context, can be seen as recognizing a congressional power to declare peace. However, closer analysis of the opinions shows that the Court was recognizing no such power."

\section{Historical practice.}

The assertion that Congress has the power to declare peace has also been based on historical practice. Professor Henkin observes that "[o]rdinarily, wars are ended by treaty, but Congress declared an end

99 Quincy Wright, The Control of American Foreign Relations 292 (MacMillan 1922).

100 John M. Mathews, The Termination of War, 19 Mich L Rev 819,831 (1921).

101 Henkin, Foreign Affairs and the United States Constitution at 370-71 n 66 (cited in note 16).

102 See text accompanying notes 75-79.

103 Ludecke, 335 US at 168.

104 See text accompanying notes 81-91.

105 See Part I.B.3. 
to both World Wars by resolution." stating that the state of war had ended following each world war; however, these resolutions do not establish a congressional power to declare peace unilaterally.

Congress's attempt to end World War I by unilateral declaration failed. ${ }^{117}$ The congressional resolution that was eventually passed should not be viewed as creating a congressional power to end war by resolution because its legal effect is not clear. Peace treaties were negotiated with each enemy. And, upon their ratification, the President issued a proclamation declaring an end to the state of war. The fact that the peace treaties and presidential proclamation recognize the date chosen by Congress as the end of the war displays respect for the congressional resolution. ${ }^{\text {tox }}$ However, it cannot be claimed as historical precedent for the claim that Congress can declare peace by joint resolution.

World War II also does not provide a historical precedent for establishing a unilateral congressional power to declare peace. The state of war with Japan was terminated in the traditional manner-by ratifying a peace treaty. ${ }^{109}$ No treaty was negotiated with Germany; instead, the legal state of war ended through a presidential proclamation issued following passage of a joint resolution signed by the President. ${ }^{110}$ This event can provide historical precedent for the claim that joint congressional-executive action can terminate a state of war; however, it does not provide support for a unilateral congressional peace power. Consequently, the actions of Congress following the two world wars do not establish by practice a congressional power to end a war without the President's agreement.

\section{B. Arguments in Favor of Creating a Congressional Peace Power}

A congressional power to declare peace lacks a firm foundation in existing law. Although Congress does not currently have the power to declare peace, arguments can be advanced to support a congressional role in terminating war. Since it is possible that the Supreme Court could be faced with the task of determining when the War on

Iok Henkin, Foreign Affairs and the United States Constitution at 76 (cited in note 16).

107 For a more detailed account, see text accompanying notes 54-61.

108 Judicial opinions determining the end of the war did not look to the congressional resolution for proof that the war had ended. Judge Hand stated in Miller, $276 \mathrm{~F}$ at 716, that World War I ended on the date established by the presidential proclamation issued upon the ratification of the peace treaties. See also notes 73-74 and accompanying text.

109 Treaty of Peace between the United States and Japan, 19523 UST 3169, TIAS No 2490 (1951).

110 See Dinstein, War, Aggression and Self-Defence at $46 \mathrm{n} 121$ (cited in note 12). 
Terrorism ends, the arguments for recognizing a congressional power should be examined.

\section{Originalist arguments.}

Those originalists who favor a congressional peace power can point to several pieces of evidence supporting their position. First is the often-quoted remark from the Constitutional Convention that it "should be more easy to get out of war, than in to it." "11 Professor Corwin relied on this statement to argue that peace should be allowed in any manner not foreclosed by the Constitution: "[T]here is more than one road leading to peace, as to Rome, and a sovereign government ... has access to them all, unless it can be shown to be cut off therefrom by some definite constitutional prohibition."112

The Framers' desire to facilitate peace, however, does not support an originalist argument for a congressional peace power. The Framers' statements, viewed in isolation, can support arguments favoring a congressional power to restore peace. But, the original understanding, when viewed as a whole, favors the primacy of the President."

The Framers' primary concern was not to ensure that war was easier to get out of than in to. ${ }^{1 / 4}$ However, even if this statement is taken as reflective of the Framers' views, whether it favors granting Congress the power to declare peace is difficult to determine. If Congress possesses the power to declare peace, then peace would be easier to achieve once a war had begun because there would be more methods to end the war. However, if Congress did not have the power to end war, it would be less likely to declare war in the first place." Since granting Congress the power to declare peace makes peace easier, but withholding the power makes war more difficult, it is unclear which option has a greater effect on the balance between peace and war.

Corwin's argument, favoring peace by any method not foreclosed by the Constitution, is unpersuasive. The Constitution, by creating a Congress of enumerated powers, makes this argument suspect as a method of constitutional interpretation. Furthermore, the debates of the Constitutional Convention show that the Framers rejected meth-

111 Madison, Journal of the Federal Convention at 548 (cited in note 23).

112 Corwin, 18 Mich L Rev at 675 (cited in note 98).

113 See Part I.A.

114 The rejection of Madison's two proposals shows that the desire for peace being easier than war was not an overriding concern. See text accompanying notes 31-35.

115 This valuable insight was made by Professor Sidak, who analogized this situation to entry and exit from an industry and noted that "[e]conomists recognize that a barrier to exit from an industry also functions $e x$ ante as a barrier to entry into that industry. The same insight regarding 'reversible entry' applies to constitutional governance." See J. Gregory Sidak, To Declare War, 41 Duke L J 27, 89 (1991). 
ods of making peace that were not explicitly forbidden in the Constitution. Corwin's method of interpretation clearly runs counter to the original intent.

Some scholars also rely on Madison's writings in response to the neutrality controversy of 1793 to support their arguments. ${ }^{116}$ Madison recognized that "the constitution has not permitted the Executive singly to conclude or judge that peace ought to be made." even offered a detailed account of why the person who conducts a war should not be able to judge when it ends. "It is in war, finally, that laurels are to be gathered, and it is the executive brow they are to encircle." "118 The desire for victory, according to Madison, is so strong that it cannot be overcome to make a rational decision whether to continue a war. According to him, "[t]he strongest passions, and most dangerous weaknesses of the human breast; ambition, avarice, vanity, the honorable or venial love of fame, are all in conspiracy against the desire and duty of peace." are to conduct a war cannot in the nature of things, be proper or safe judges, whether a war ought to be commenced, continued, or concluded." ${ }^{, 211}$ Because the President stands to gain so much by waging war, he cannot be trusted to decide whether war should end.

Madison's "Helvidius" argument appears unrepresentative of the beliefs of the majority of the Framers. Madison made a similar argument at the Constitutional Convention when he proposed allowing a two-thirds vote by the Senate to make a treaty without presidential consent. The Framers rejected this proposal, which should make us wary of claiming this argument as reflective of the original intent. Furthermore, the fact that Madison's argument was not accepted when it was made renders it an even more questionable interpretation of the peace power.'

116 The neutrality controversy arose following France's declaration of war on Great Britain. It was arguable that the United States had a treaty obligation to enter the war on France's behalf, but President Washington issued a proclamation announcing the country's neutrality. Madison and Hamilton famously debated whether the President or Congress had the power to decide that the United States would remain neutral. For a more complete account of this controversy, see H. Jefferson Powell, The President's Authority over Foreign Affairs: An Essay in Constitutional Interpretation 47-51 (Carolina 2002).

117 "Helvidius" No 4 (Madison), in Thomas A. Mason, Robert A. Rutland, and Jeanne K. Sisson, eds, 15 The Papers of James Madison 110 (Virginia 1985).

118 Id at 108.

119 Id.

120 "Helvidius" No 1 (Madison), in Mason, Rutland, and Sisson, eds, 15 Papers of James Madison at 66, 71 (cited in note 117).

121 See Abraham D. Sofaer, War, Foreign Affairs and Constitutional Power: The Origins 115 (Ballinger 1976) ("The theory advocated by Madison in 1793 as to the appropriate roles of President and Congress had been rejected in practice even before his Helvidius papers saw the light of day."). 


\section{Appropriations power.}

Another argument in favor of recognizing a congressional power to end war is based on the fact that Congress can withhold funding for a war, bringing the fighting in the war to an end. This power to exercise control over whether military operations continue is distinct from the power to end the legal state of war. However, since Congress can bring the fighting to an end, it arguably should be allowed to terminate the state of war as well. Granting Congress this additional power might seem attractive since withholding military funding is undesirable: The reduction of funding would lead, in the period prior to the end of the war, to less-effective waging of war, putting the lives of American soldiers in danger. Withholding funding is procedurally easier than declaring peace over a presidential veto because a simple majority in either the House or Senate can prevent the necessary appropriations bill from being passed. Given that declaring peace requires broader support than withholding funding, it may be argued that Congress should be granted the power to declare peace so that it can end war directly.

But the very fact that withholding appropriations can place a strong check on the President's ability to wage war cuts against the argument that the appropriations power is a basis for granting Congress the power to terminate war. It was precisely because the appropriations power would check the President that some of the Framers did not think it necessary to allow Congress to declare peace. ${ }^{122}$ Since the appropriations power still checks the President's war-making power, we should not lightly reject the Framers' balancing.

\section{Absence of a negotiating partner.}

The Supreme Court has recognized a congressional power to pass legislation in some situations where a treaty is ordinarily required, but no negotiating partner is available. One could argue that the Court should do the same for the power to terminate the War on Terrorism since there is no party with whom the United States could negotiate a peace treaty.

Professor John Mathews argued in favor of a congressional power to restore peace by analogizing to its power to acquire new territory. "The usual method of acquiring territory has been by treaty," but "the power of Congress to do so by statute or joint resolution is recognized as proper where there is no foreign government with

122 See paragraph accompanying note 38 .

123 See Mathews, 19 Mich L Rev at 831 (cited in 100).

124 Id. 
which a treaty can appropriately be made. ${ }^{\prime 125}$ Likewise, Congress could possess the power to restore peace when there is no foreign government with which to negotiate.

That Congress should have the power to terminate war because it has the power to acquire territory is a strong argument. However, there are good reasons to distinguish between the two situations. Insofar as territory is acquired with the intention of granting statehood, the Court acted reasonably in recognizing this congressional power since Congress's approval would be needed to make the territory a state. ${ }^{126}$ In the context of war termination, no subsequent constitutional power of Congress is implicated.

Furthermore, the President plays a key role in terminating war for reasons other than his ability to negotiate in secrecy. Even when there is no possibility of negotiating a peace treaty, the President's access to superior information concerning the war puts him in a better position than Congress to determine whether the war should end. Because these concerns are not present in the decision to acquire territory, it is reasonable to distinguish between acquiring land and terminating war.

The arguments in favor of creating a congressional power to declare peace are not sufficiently compelling to depart from the Court's view in Hamilton. This conclusion is even more apparent after examining the advantages of presidential control of war termination, which is the focus of Part III.

\section{Presidential Control of the Peace Process}

The Supreme Court has recognized that the state of war can be terminated by a proclamation of peace, which seems to grant the President the power to declare peace unilaterally. Recognizing a presidential power to declare peace unilaterally is proper for three reasons. First, presidential primacy in terminating the state of war is consistent with the original understanding and existing case law. Second, the President's role as "sole organ" of foreign affairs puts the President in the best position to announce the nation's decisions. Third, the President, as Commander-in-Chief, has access to superior information that allows him to make the best decision about whether the war should end. This Part examines each of these rationales and shows that these advantages continue to support the President's power, particularly in an unconventional war like the War on Terrorism.

126 US Const Art IV, \$ 3, cl 1. 


\section{A. Original Understanding and Supreme Court Precedent}

The Framers were aware of the threat posed by placing the peace power in the hands of a single person. Madison was especially fearful of giving the President too much power to wage war and proposed changes to the constitutional distribution of war powers. The Framers rejected Madison's proposals because they believed the appropriations power provided a sufficient check on the President. ${ }^{127}$ The Framers' belief was reasonable. Congress had the power to declare war and to raise armies, in addition to the appropriations power. By contrast, the English Parliament possessed only the appropriations power, yet, as Justice Story noted, "this is found to be abundantly sufficient to protect the nation against any war against the sense of the nation, or any serious abuse of the power in modern times."128

The Framers' belief that the President should be involved in the peace process has been respected by the Court's decisions on the power to terminate war. The two methods, peace treaty and proclamation of peace, recognized by the Court following World War I both require presidential involvement. The Supreme Court did nothing to change this position following World War II, and lower courts have relied on the Court's post-World War I view. ${ }^{129}$ One post-World War II commentator even referred to "looking only to a treaty or formal executive proclamation" as the "traditional test" for determining whether the legal state of war had ended. ${ }^{130}$.

Both the original understanding of the power to terminate war and existing Supreme Court precedent on the subject support requiring the President's concurrence in ending the War on Terrorism. Overturning this precedent and rejecting the original understanding to allow Congress to end the War on Terrorism unilaterally is unwarranted absent the existence of compelling reasons. Compelling reasons do not exist. Instead, the unique aspects of the War on Terrorism strengthen the case for presidential involvement.

127 See text accompanying notes $34-37$.

128 Story, 2 Commentaries on the Constitution $\$ 1492$ at 362 (cited in note 22).

129 See, for example, The Elqui (ex Selma), 62 F Supp 764, 767 (ED NY 1945) (noting that the state of war ended upon "the formal signing of a peace treaty or a proclamation by the sovereign that the war has been officially recognized as being at an end"), citing Hamilton, 251 US 146; Citizens Protective League v Byrnes, 64 F Supp 233, 234 (D DC 1946) (stating that "the period of war has been held to extend to the ratification of the Treaty of Peace or the Proclamation of Peace").

130 Case Note, Enemy Alien-Termination of War-Unconditional Surrender, $95 \mathrm{U} \mathrm{Pa} \mathrm{L}$ Rev 416,418 (1947). 


\section{B. "Sole Organ" of Foreign Affairs}

United States domestic law recognizes that the President possesses the exclusive right to speak on behalf of the nation. ${ }^{131}$ The most famous statement of this role, by then-Representative John Marshall, was adopted by the Supreme Court in United States v Curtiss-Wright Export Corp: " "The President is the sole organ of the nation in its external relations, and its sole representative with foreign nations.",3.3

An incident involving French diplomat Edmond Charles Genet provides a valuable insight into the original understanding of the ability of the President and Congress to speak on behalf of the nation. Genet, thinking that Congress was more sympathetic toward the plight of the new French Republic, challenged the President's foreign affairs authority by addressing his commission to Congress instead of the President. ${ }^{1.4}$ The commission was returned by Secretary of State Thomas Jefferson, along with the following message:

[The President] being the only channel of communication between this country and foreign nations, it is from him alone that foreign nations or their agents are to learn what is or has been the will of the nation; and whatever he communicates as such, they have a right, and are bound to consider as the expression of the nation. ${ }^{135}$

Congress has passed resolutions expressing its view on matters of foreign relations, but its actions are generally not thought to be sufficient to challenge the President's exclusive power to speak on behalf of the United States.

As the chief representative of the United States, the President is in the best position to announce the nation's decision to terminate war. A presidential proclamation declaring peace would clearly signal to the rest of the world that the United States is no longer at war. A congressional resolution passed over a presidential veto might create uncertainty among other nations as to whether the United States was

131 See Henkin, Foreign Affairs and the United States Constitution at 42 (cited in note 16) ("That the President is the sole organ of official communication by and to the United States has not been questioned and has not been a source of significant controversy.").

132299 US 304 (1936).

133 Id at 319.

134 See Saikrishna B. Prakash and Michael D. Ramsey, The Executive Power over Foreign Affairs, 111 Yale L J 231, 321 (2001).

135 Letter from Thomas Jefferson to Edmond Charles Genet (Nov 22, 1793), in Paul Leicester Ford, ed, 6 The Writings of Thomas Jefferson 451 (G.P. Putnam's Sons 1895).

136 See Prakash and Ramsey, 111 Yale $\mathrm{L} J$ at 320 n 384 (cited in note 134) ("While Congress is free to pass nonbinding 'sense of the Congress' resolutions about foreign affairs matters and it may ask the President to convey messages to foreign governments or peoples, it cannot purport to speak on behalf of the United States."). 
still at war because international law generally recognizes the President as head of state and the nation's spokesman."

This role as the nation's spokesman puts the President in a position to affect the existence of a state of war under international law. Since terminating the state of war is important under both domestic and international law, a method that ends both states of war should be preferable to one whose effect on international law is uncertain. A presidential proclamation is superior to a congressional resolution for this purpose.

Making a definitive statement of the United States's position to the rest of the world is even more important in the War on Terrorism than in previous wars. In traditional wars, the position of one nation can often be inferred from statements or actions of other nations involved in the war. The lack of an enemy with a voice in the international community puts the United States in the position of being the lone source for determining the status of the War on Terrorism.

\section{Institutional Advantages}

In order to determine whether either Congress or the President should possess the power to terminate war unilaterally, it is instructive to examine each branch's comparative advantages. An important institutional advantage of the President arises from the Constitution's vesting of the executive power in a single person. Alexander Hamilton, in Federalist 70, recognized this advantage and wrote: "Decision, activity, secrecy, and dispatch will generally characterize the proceedings of one man, in a much more eminent degree, than the proceedings of any greater number.",1..6 These advantages are particularly important during war, which makes the Framers' choice of the President to act as Commander-in-Chief a good one..$^{1.39}$ As Professor John Yoo has pointed out, "The centralization of authority in the President is particularly crucial in matters of national defense, war, and foreign policy, where a unitary executive can evaluate threats, consider policy choices, and mobilize national resources with a speed and energy that is far superior to any other branch."

By controlling military operations as Commander-in-Chief, the President gains access to better information about the conduct of the

137 See Robert Jennings and Arthur Watts, eds, 1 Oppenheim's International Law $\$ 446$ at 1034 (Longman 9th ed 1992) ("The Head of a State is competent in international law to act for his state in its international intercourse ... This competence ... [includes] conclusion of treaties, declaration of war, and conclusion of peace.").

138 Federalist 70 (Hamilton), in Jacob E. Cooke, ed, The Federalist 471, 472 (Wesleyan 1961).

139 US Const Art II, $\S 2, \mathrm{cl} 1$ ("The President shall be Commander in Chief of the Army and Navy of the United States ....").

140) Yoo, $69 \mathrm{U}$ Chi L Rev at 1676 (cited in note 8). 
war than Congress does. Because the President is better informed about the conduct of the war, he is in a better position to determine whether it should end. This advantage was not discussed at the Convention, but was recognized during the debate over the Jay Treaty in an early Congress. Representative Holland of North Carolina argued:

[The President] is declared Commander-In-Chief of all the Armies, his situation enabled him to be the best judge of the forces and of the force he had to contend with, and as secrecy was necessary to effecting a Treaty of Peace, that power was properly vested in him, guarded by two-thirds of the Senate. ${ }^{191}$

The President's access to information has never been as significant an advantage as it is in the War on Terrorism. Because highly sensitive intelligence reports are required to determine the location, and even the existence, of the enemy, the President is in a superior position to determine whether the war should be terminated. Of course, the intelligence information could be shared with Congress to reduce the President's information advantage. And, in practice, the President will often share confidential information with select members of Congress. However, Congress is not designed to be a body to which the nation's secrets are entrusted. Dissemination of confidential intelligence reports would increase the chance that the information would be obtained by the nation's enemies, and few of the advantages possessed by a deliberative body could be realized, since the information could not be openly discussed.

Withholding the power to declare peace from Congress changes its war-making powers in ways that play to its institutional advantages. Congress's primary institutional advantage lies in its ability to produce decisions by a deliberative body composed of divergent viewpoints and interests. The greater the importance of Congress's decision to declare war or authorize the use of force, the more deliberation that can be expected and the less likely that Congress will rush into war. ${ }^{1.2} \mathrm{~A}$ Congress, knowing that it cannot end the state of war without the President's agreement, can be expected to deliberate more thoroughly when deciding whether to declare war. As George Mason desired, this outcome "clog[s], rather than facilitat[es] war." the President, and not Congress, to declare peace unilaterally plays to the strengths of both institutions.

1415 Annals of Cong 546-47 (March 14, 1796) (Gales and Seaton 1849).

142 See Sidak, 41 Duke $\mathrm{L} J$ at 89 (cited in note 115). See also note 115 and accompanying text.

143 See Madison, Journal of the Federal Convention at 548 (cited in note 23). 


\section{Congressional Checks}

If Congress could not otherwise effectively check the President's war-making power, recognizing a congressional power to declare peace might be reasonable. However, Congress's power to declare war and appropriate money provide sufficient checks. The Declare War Clause provides an important check: Not only does it give Congress the power to initiate war, but it also gives Congress the power to limit the scope of the war. ${ }^{144}$

Congress exercised its power to limit the scope of war when it authorized the use of force in the War on Terrorism. Congress limited the scope of the war to "those nations, organizations, or persons [that the President] determines planned, authorized, committed, or aided the terrorist attacks that occurred on September 11, 2001."145 Congress also stated its purpose for authorizing force: "to prevent any future acts of international terrorism against the United States by such nations, organizations or persons." ${ }^{140}$ While this authorization is broad, it is undoubtedly narrower than a declaration simply stating that the United States is at war.

Once force has been authorized, Congress still has a significant check on the President through its appropriations power. The strength of the appropriations power is apparent from Congress's role in bringing the military operations in Vietnam to an end. In June 1973, Congress passed a general appropriations bill to which it attached an amendment that "simply cut off the bombing in Cambodia." dent Nixon vetoed the bill and the House failed to override the veto. ${ }^{1+4}$ Following a conference between Senator Fulbright and White House officials, ${ }^{t, y}$ a modified amendment was proposed by Fulbright which stated that "on or after August 15,1973, no funds herein, heretofore or hereafter appropriated may be obligated or expended to finance the involvement of United States military forces in hostilities in or over or from off the shores of North Vietnam, South Vietnam, Laos, or Cambodia." ${ }^{1.50}$ The revised amendment was passed and this time signed by President Nixon, who, pursuant to the amendment, terminated bombing on August 14, 1973. ${ }^{1.1}$ Although the President's veto power prevented Congress from immediately withdrawing funding, the appro-

\footnotetext{
144 See text accompanying notes $95-98$.

145 Authorization for the Use of Military Force, 115 Stat at 224.

146 Id.

147 Ely, War and Responsibility at 39 (cited in note 16).

148 Id.

149 Id.

150) Fulbright Amendment to H J Res 636, 93d Cong, 1st Sess, in 119 Cong Rec S 22,305 (June 29, 1973).

151 See Ely. War and Responsibility at 41 (cited in note 16).
} 
priations power gave Congress enough leverage to convince Nixon to agree to stop bombing the following month. Thus, the appropriations power provided a check on the President, just as the Framers had envisioned.

The appropriations power can provide a check on the President's authority to wage war in the War on Terrorism. As Professor Yoo has noted, "In the war against the al Qaeda terrorist organization and the Taliban militia in Afghanistan, ... President George W. Bush sought additional funding for military operations, giving Congress the opportunity to oppose hostilities... Congress could have effectively blocked the conduct of hostilities by refusing to appropriate the funds." ".52 Congress has not attempted to block funding for the War on Terrorism, and thus it is difficult to argue that Congress should have the power to declare peace unilaterally because its traditional checks on the President are insufficient. Because the powers to declare war and appropriate funding still provide Congress with checks on the President's war-making ability, there is no reason to reject the President's role in the peace process.

\section{CONCLUSION}

The Framers' original understanding and the early case law recognize the ratification of a peace treaty as the method for ending the state of war under domestic law. The restoration of peace with Germany following World War II implies that joint congressionalexecutive action can also terminate the state of war. The Hamilton Court, at the end of the Civil War, concluded that the state of war could also be terminated by a proclamation of peace. Hamilton recognizes the power of the President to declare peace unilaterally, since proclamations of peace are traditionally issued by the President.

The circumstances surrounding the War on Terrorism do not warrant rejecting the Constitution's original understanding or existing Supreme Court precedent. While numerous arguments have been advanced for a congressional power to declare peace, none is sufficiently compelling to depart from the Hamilton Court's statement of the methods for terminating war. A peace treaty and presidential proclamation, as well as joint congressional-executive action, all require the President's agreement. As a result, contrary to the widely held view, Congress cannot unilaterally declare peace by passing a peace resolution over a presidential veto. 


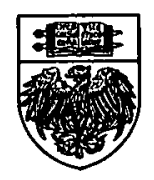

